\title{
Edmodo-Based Learning and the Students' Perception
}

\author{
Andi Febriana Tamrin', Basri² \\ 1,2Universitas Fajar, Makassar, Indonesia \\ 'Email: andifebrianago@unifa.ac.id
}

Submitted: 12/11/2019

Revised: 07/12/2019

Accepted: 20/01/2020

E-ISSN : $2579-4574$

P-ISSN : $2549-7359$

\begin{abstract}
In the 4.0 era, technology is taking a part of many fields, including education. This research aimed is to find out about the perception of students about English class based on online method using Edmodo as medium. Descriptive qualitative method is used in this research. The respondents are the students who took English class and came from different department. This shows that the students preferred online method by using Edmodo for English Class. However, there is still drawbacks of using it.
\end{abstract}

Keywords: Online Learning, Edmodo, English Class

https://ojs.unm.ac.id/eralingua

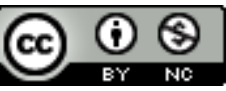

This work is licensed under a Creative Commons Attribution-NonCommercial 4.0 International License. 


\section{INTRODUCTION}

Learning method and media are two of the most crucial in learning process (Eslami \& Ahmadi, 2019; Stathopoulou, Siamagka, \& Christodoulides, 2019; Al-Qasyi, Mohamad-Nurdin, \& Al-Imranm 2020). Both of them are important because their position as tools used for teaching. In term of the position, learning media are a single unit with the learning method. Bentley et al. (2012) said that online learning is a sophisticated learning method which connects teachers and students to have learning process without having to attend in class. This phenomenon has emerged and blended into the world of education in this 4.0 era and become the beginning of E-learning method.

Learning media has a function as a tool to support the learning process that can be accessed and used by lecturers. Online media is the media chosen by schools and universities in order to help them in learning process. One of the most famous of online platform media is Edmodo. This application has been developed by Jeff O'Hara and Nick Borg since 2008 and can be used free of charge. This application can make learning process more interesting and easier to use. In addition, this application makes learning more flexible. In addition, using Edmodo for students could help them to interact and communicate more efficiently with their lecturers. Also, it could find it easier to access lecture materials those are shared through this application. There are many kinds of teaching material that can be uploaded such as text, images, audio and video.

As an international language, English is a must for students to learn nowadays. It is because many aspects of life, including in the work field demand the worker to use English, at least passively, as part of their communication. However, not all people could teach and learn English easily. It is a challenge for lecturer to teach their students. They are faced by old wife tale that English is often considered difficult for students. Sometimes, attracting students' attention could become a challenge for lecturers. The general problem faced by them is a monotonous teaching style, a lack of learning media that is able to attract the student to participate in learning process (Putri \& Solfema, 2019; Elmunsyah, Hidayat, \& Asfani, 2019; Aro et al., 2019).

By implementing Edmodo as learning media, it could change the perspective of students in learning English. The existence of Edmodo as friendly LMS (Learning Managemen System) in education world is one of the reasons why it was chosen in this research. Moreover, for the lecturer, Edmodo is known as "subject communities" (Trust, 2017). It refers to the feature that Edmodo provided. It makes the lecturer finding and sharing their knowledge.

Edmodo is proposed as a simple solution in order to get most of teaching and learning activity. It is because Edmodo has such simple appearance. It has many kinds of facilities such as grade-book, quiz, and pool for lecturers/teachers to use. It is easy to accessed and compatible to both android and iOS devices. Moreover, there is a facility that the third party could join, which is for parent to control their children grade and performance.

There are several previous researches that has been done and used Edmodo as the object. Komara and Ramdani (2014) research about motivating students by 
applying Edmodo. The aimed for their research was to fiond out the motivation of students in learning by using Edmodo. The scope of this research is in Grammar class. The result showed that Edmodo contributed positively in English grammar class. Then, Ekici (2017), used Edmodo to create an online community of practice to teach science. Also, the research focused more to the teacher not students (Ekici:2017). It depicted that Edmodo can be used to create an online community of practice in theacer education programmes.

Then, Trust (2017) did research about the motivation, empowerment and innovation from teachers' beliefs. This research designed to examine how K-12 teachers' participation in the Edmodo math subject community, could shaped their learning and practice (Trust, 2017). It concluded that Edmodo could help participants in their subject of teaching. Through online spaces in Edmodo, they gained many inspirations to be more innovative and they were able to make changes in their practice.

Lastly, the research about Edmodo is done by Yin in 2018. This research aimed to examine the effects of mobile learning towards undergraduates' performance and interest in Malaysia (Yin et al., 2018). According to the researchers, mobile collaborative learning approach needs to be implemented on the online environment. The students of Economics did not have many understandings about the concept of Economics and the ability in reasoning compared to normal graduates (Yin et al., 2018). As the result, the findings indicated that Edmodo contributes significant positive effects towards students' performance, interest and collaborative problem solving skills.

The purpose of this study is to find out about the perception of the students' in using online media for learning English for students at Universitas Fajar. Even though there are many different opinions about the relation of students' perception and their achievement, this research focused on the affirmative side. The reason because the result of the research has been proven. The link of perception and students' achievement is related to each other. Some studies have been done before. The students feel that they could learn better if they have a good perception towards their method of learning (Balasubramanian et al., 2014). Moreover, in the EFL classroom creativity is needed to make the students comfortable in their environment. Providing a useful and beneficial learning tool is a good way to do. By providing them with this, the students could give a good perception. As the result, their motivations, flexibility and participation in online learning activities are increasing, which is mean the impact to achievement is positive (Manowong, 2016). In addition, Gietz and McIntosh (2014) proved that the connection between perceptions of students and their school environment were significantly associated with their academic success. Turn out the environment is also playing a major role for this (Gietz and Mclntosh, 2014).

Compared to previous researches, the novelty of this research is on the object which is University Students who programmed English as their subject. Moreover, the students came from different majors. This research is expected to give contribution for other researchers and lecturers to encourage them in using online media for their class. Theoretically, this study could provide more information 
on e-learning, educational technology and media development. Therefore, research on online media for learning process could provide many people about the students' perception and acceptance of online learning process.

\section{RESEARCH METHOD}

In this research, the descriptive percentage method is used. This method is chosen because it could help the researcher to find data and describe research results. The respondents in this study are students in Universitas Fajar who came from three different departments, namely; Architecture, Management, Accounting S1 and D3 who had programmed English class S. This research is conducted in 2019 at Universitas Fajar. For sampling, the purposive sampling method is used. This method was found suitable because of it is based on the expertise of the surveyor. It is also providing other advantages in the form of accuracy of researchers in selecting data sources in accordance with variables studied. The reason why purposive sampling used in this study is because researcher would like to find out the perception of both the highest score student and the lowest score student those passed this subject. Does Edmodo affect their score or not?

The instruments of the data collection are questionnaire and interview. Questionnaire consists 11 point of questions to find out students' perception of Edmodo role in changing student learning style and Edmodo role and performance itself. Interview consists 5 questions to support the student perception questionnaire of Edmodo roles and performances.

The data analysis techniques applied in this research is descriptive. Descriptive research is used to obtain data about students' perceptions of the use of online teaching materials and the implementation of Edmodo in learning process of English class. The data analysis is done by selecting, sorting, grouping, existing data, summarizing it and presenting it in narrative form. Presentation of the result of qualitative data analysis is made in the form of a brief description, or table in accordance with the nature of data analyzed. Presentation of data analyzed using descriptive statistical analysis is the calculation of presentation.

\section{RESULT AND DISCUSSION}

\section{Result from Questionnaire}

Based on the questionnaire that was distributed to the Accounting classes, both of S1 and D3, Architecture and Management who programmed English, as many as 100 responses have been collected from a total of 4 classes that have been adjusted to the number of samples. The result shows that the students' perceptions of using Edmodo as media of learning are positive or they are agreeing or strongly agree. The detailed of the result can be seen from the table below: 
Table 1. The Role of Edmodo in Changing Students' Learning Style

\begin{tabular}{|c|c|c|c|c|c|c|c|c|}
\hline \multirow{2}{*}{$\begin{array}{l}\text { The use of } \\
\text { Edmodo as } \\
\text { Supportive } \\
\text { Learning } \\
\text { Medium }\end{array}$} & \multicolumn{5}{|c|}{ Scale } & \multirow{2}{*}{$\begin{array}{l}\text { The } \\
\text { Highest- } \\
\text { scale } \\
\text { Percentage }\end{array}$} & \multirow[t]{2}{*}{ Average } & \multirow{2}{*}{$\begin{array}{c}\text { Categ } \\
\text { ory }\end{array}$} \\
\hline & $\begin{array}{c}\text { Very } \\
\text { Disagree }\end{array}$ & Disagree & Neutral & Agree & $\begin{array}{l}\text { Highly } \\
\text { Agree }\end{array}$ & & & \\
\hline $\begin{array}{l}\text { The use of Edmodo } \\
\text { Changes } \\
\text { Style }\end{array}$ & 2 & 0 & 8 & 63 & 27 & $63 \%$ & $57,2 \%$ & Agree \\
\hline $\begin{array}{l}\text { The Use of Edmodo } \\
\text { eases } \\
\text { submission }\end{array}$ & 0 & 0 & 5 & 46 & 49 & $49 \%$ & & $\begin{array}{l}\text { Highly } \\
\text { Agree }\end{array}$ \\
\hline $\begin{array}{l}\text { The use of Edmodo } \\
\text { reduces the cost } \\
\text { burden in paper } \\
\text { assignment }\end{array}$ & 0 & 1 & 2 & 21 & 76 & $76 \%$ & & $\begin{array}{l}\text { Highly } \\
\text { Agree }\end{array}$ \\
\hline $\begin{array}{l}\text { The use of Edmodo } \\
\text { enhances } \\
\text { technological skill }\end{array}$ & 0 & 1 & 7 & 45 & 47 & $47 \%$ & & $\begin{array}{l}\text { Highly } \\
\text { Agree }\end{array}$ \\
\hline $\begin{array}{l}\text { The use of Edmodo } \\
\text { increase learners' } \\
\text { participation }\end{array}$ & 0 & 1 & 23 & 55 & 25 & $51 \%$ & & Agree \\
\hline
\end{tabular}

According to the data presents in the table, the five questions results are showing those students perceptions of Edmodo are positive. They accept Edmodo to be used as a learning media. The most effective things those Edmodo gives to students which reduce the costs of their paper assignment and improving their technological skill. In this question, students' perceptions are highly agree, because they found out the function of Edmodo as a learning media. The conclusions, students learning style is affecting by Edmodo. Their learning style is from paper to paperless and from write in book to type in laptop/smartphone. The second table below displays participants' responses on the role and the use of Edmodo when used during the learning process. This includes its convenience, communication between lecturers and students, and course materials delivery.

According to the table 2, student perceptions toward Edmodo role and performance are positive. Students agree that Edmodo is convenient to use in learning. The function of Edmodo, which making student easier to get the learning materials is accepting by students. Every student could accept the materials wherever they are when the materials are uploaded. Edmodo is also easy to use. On the other hand, Edmodo also ease the communication between students and lecturers. Nowadays, some students are too shy or afraid to ask to the lecture about their assignment or materials directly. Edmodo helps them to communicate to lecture by giving comments in the comment section of the given materials. 
Table 2. Students' Responses towards the Role and Performance of Edmodo

\begin{tabular}{|c|c|c|c|c|c|c|c|c|}
\hline \multirow{2}{*}{$\begin{array}{l}\text { The use of } \\
\text { Edmodo as } \\
\text { Supportive } \\
\text { learning } \\
\text { medium }\end{array}$} & \multicolumn{5}{|c|}{ Scale } & \multirow{2}{*}{$\begin{array}{l}\text { The } \\
\text { Highest- } \\
\text { scale } \\
\text { Percent } \\
\text { age }\end{array}$} & \multirow[t]{2}{*}{ Average } & \multirow{2}{*}{$\begin{array}{c}\text { Categor } \\
y\end{array}$} \\
\hline & $\begin{array}{c}\text { Very } \\
\text { Disagree }\end{array}$ & Disagree & Neutral & Agree & $\begin{array}{l}\text { Highly } \\
\text { Agree }\end{array}$ & & & \\
\hline $\begin{array}{l}\text { Edmodo-based } \\
\text { method is better } \\
\text { than conventional } \\
\text { method }\end{array}$ & 2 & 0 & 8 & 63 & 27 & $63 \%$ & $57,1 \%$ & Agree \\
\hline $\begin{array}{l}\text { Edmodo eases } \\
\text { communication } \\
\text { between lecturer } \\
\text { and students }\end{array}$ & 0 & 0 & 5 & 46 & 49 & $49 \%$ & & $\begin{array}{l}\text { Highly } \\
\text { Agree }\end{array}$ \\
\hline $\begin{array}{l}\text { Course materials } \\
\text { could be directly } \\
\text { accessed by students }\end{array}$ & 0 & 1 & 2 & 21 & 76 & $76 \%$ & & $\begin{array}{l}\text { Highly } \\
\text { Agree }\end{array}$ \\
\hline It is easy to use & 0 & 0 & 5 & 50 & 45 & $50 \%$ & & Agree \\
\hline $\begin{array}{l}\text { Social-media based } \\
\text { learning is more } \\
\text { efficient }\end{array}$ & 0 & 2 & 12 & 55 & 31 & $55 \%$ & & Agree \\
\hline $\begin{array}{l}\text { Materials delivery } \\
\text { through Edmodo is } \\
\text { more efficient }\end{array}$ & 0 & 0 & 13 & 50 & 37 & $50 \%$ & & Agree \\
\hline
\end{tabular}

\section{Result of the Interview}

After distributing the questionnaire, the research is continued using interview method. Interview samples are chosen using Purposive sampling which are choosing 3 students from each class with 2 indicators. The Indicators are 1) The highest score student, 2) the lowest attendance student who is passing this study successfully. The interview consisted of five questions related to the use of Edmodo social media as teaching material and also related to the questionnaire. The interview questions and results from the two students from each class as follows.

Based on the results of interviews of 8 students who have been selected, it can be concluded that their responses to Edmodo are quite satisfying, agreeable or positive. Edmodo not only helps students who are basically already diligent, but also makes it easier for students with less attendance. These students can still do and collect their assignments before the allotted time to make them successfully pass this English class, with a fairly low attendance.

The result of this research is in line previous research which used Edmodo as the object. Edmodo should be regarded as one of a good tool in blended learning. It is proven that it could be very helpful in increasing students' creativity, flexibility, interpersonal and teamwork skill development (Manowong, 2016). Edmodo has given many positive influences toward the users. Not only for the students, but also for the teachers. It is definitely a very useful virtual community in which many people could join for free. For example, Trust (2017) found out that online spaces 
such as Edmodo gave very positive outcome for Math teachers. They feel they could make changes into their practice of teaching. Also, they were able to adopt innovative, student-centered practices (Trust, 2017).

Edmodo-based online learning certainly has its pros and cons. Edmodo which is applied in the learning process has its own impressions and opinions for individual students. From the results of the questionnaire responses (table 2), the percentage shows that most students agree with Edmodo implementation in the learning process. In terms of the 11 questions, 6 out of 11 questions indicate that students agree and 5 out of 11 questions agree strongly, so it can be concluded that the students' perception of Edmodo is good.

As for some of the obstacles experienced by some students, this was revealed after researchers conducted interviews with 8 students, each of 2 from each study program with indicators, namely: 1) Students with the highest final grade; 2) Students with the lowest attendance. The obstacles they experienced were, ranging from internet connection problems, limited file size that could be uploading, and inadequate cell phones.

The results of this study indicate students' perceptions of the use of online teaching materials and the application of Edmodo in lectures in English classes, namely: 1) The use of online teaching materials provides many benefits and convenience for students, especially those with low student attendance. This can be seen from the responses to the questionnaires that have been distributed, as well as the results of the interviews. Students who are low in attendance are provided with ease in workmanship and task collection, so that their grades remain in, even though they are absent, and they also still get teaching material given on the day they are absent; 2) The application of Edmodo in lectures in the English class can be well received by students. Students who have previously been preoccupied with recording material given by lecturers on the board or in power point presentations can focus more on explaining the material provided by the lecturer. This is because the material they need to record they have received on Edmodo application. The application of Edmodo also helps students to be more disciplined in working on assignments because depositing assignments on the Edmodo application requires students to complete and deposit their assignments before the deadline given.

\section{CONCLUSION}

To conclude, the study illustrates that learners show great support on the use of Edmodo as the medium of learning. Moreover, they could gain some great benefits through this application including having better learning style and morepractical learning, being more discipline when completing assignment, and becoming a great assistance for those who could not attend lectures. Nevertheless, as it is just recently applied, some obstacles are still existent.

\section{ACKNOWLEDGMENTS}

This study was funded by Ministry of Research, Technology and Higher Education under Junior Lecturer's Grant in 2019. 


\section{REFERENCES}

Al-Qaysi, N., Mohamad-Nordin, N., \& Al-Emran, M. (2020). A systematic review of social media acceptance from the perspective of educational and information systems theories and models. Journal of Educational Computing Research, 57(8), 2085-2109.

Aro, T., Eklund, K., Eloranta, A. K., Närhi, V., Korhonen, E., \& Ahonen, T. (2019). Associations between childhood learning disabilities and adult-age mental health problems, lack of education, and unemployment. Journal of Learning disabilities, 52(1), 71-83.

Balasubramani, Kandappan \& Jaykumar, Leena N.K. (2014). Student Preference Towards The Use of Edmodo as A learning Platform to Create Responsible Learning Environment. Proceeding, Asia Euro Conference. Selangor: School of Hospitality, Tourism and Culinary Arts.

Bentley, Y., Habte, S., and Anjali Shegunshi. (2012). Design and Evaluation of Student-Focused eLearning. The Electronic Journal of e-Learning, Volume 10 Issue I, 2012, page 1-12.

Ekici, Didem Inel. (2017). The Use of Edmodo in Creating an Online Learning Community of Practice for Learning to Teach Science. Malaysian Online Journal of Educational Science, Volume 5 Issue 2.

Elmunsyah, H., Hidayat, W. N., \& Asfani, K. (2019, April). Interactive learning media innovation: utilization of augmented reality and pop-up book to improve user's learning autonomy. In Journal of Physics: Conference Series (Vol. 1193, No. 1, p. 012031). IOP Publishing.

Eslami, R., \& Ahmadi, S. (2019). Investigating the role of educational media on secondary school students' learning process improvement in Jahrom city. Journal of Humanities Insights, 3(01), 13-16.

Gietz, Carmen and Mclntosh, Kent. (2014). Relations Between Student Perceptions of Their School Environment and Academic Achievement. Canadian Journal of School Psychology, Vol 29 (3) 161-176.

Komara, U and Ramdani, Junjun Muhammad. (2014). Motivation Students through Edmodo (A blended Learning in Grammar Class). Proceeding of The 61 TEFLIN International Conference. UNS: Solo.

Manowong, Supaporn. (2016). Undergraduate Students' Perceptions of Edmodo as A Supplementary Learning Tool in an EFL Classroom. Journal of Social Sciences, Humanities and Arts, Vol. 16(2):137-161. Silapkorn University.

Putri, M. P., \& Solfema, S. (2019). The Relationship Between Variations in the Use of Learning Media and the Learning Activity of Citizens Learning. Indonesian Journal of Contemporary Education, 1(1), 36-40.

Stathopoulou, A., Siamagka, N. T., \& Christodoulides, G. (2019). A multi-stakeholder view of social media as a supporting tool in higher education: An educatorstudent perspective. European Management Journal, 37(4), 421-431

Trust, Torrey. (2017). Motivation, Empowerment, and Innovation: Teachers' Beliefs about How Participating in the Edmodo Math Subject Community Shapes 
72 Eralingua: Jurnal Pendidikan Bahasa Asing dan Sastra Vol.4, No.1, March 2020

Teaching and Learning. Journal of Research on Technology in Education, Volume 49, Nos. 1-2 pp 16-30.

Yin, K.Y., Yusof, R., Lok, S.Y.P., \& Zakariya, Z (2018). The Effect of Collaborative Mobile Learning Using Edmodo among Economics Undergraduates. International Journal of Academic Research in Progressive Education and Development, 7 (3), 40-47. 